\title{
Measuring Internet Banking Service Quality in India: An Empirical Study
}

\section{Syed Shahzeb Saleem* and Mohammad Adil**}

\begin{abstract}
The measurement of Internet banking services is a key management activity that provides information necessary for making effective decisions, monitoring performance, and allocating resources effectively. In this context, the E-S-QUAL scale is widely used to measure service quality in various service industries. This study attempts to measure Internet banking service quality in India based on data collected from a sample of 274 respondents through nonprobability-based convenience sampling. In order to test the reliability of the scale and determine if there are significant differences between respondents' demographic variables and factors related to E-S-QUAL, we employ Cronbach's alpha (reliability test), the t-test, ANOVA, and correlation analysis. Our preliminary analysis indicates that, in terms of internal consistency/reliability, the E-S-QUAL (when applied to India) performs just as a scale measuring service quality should. The findings suggest there are no significant differences across respondents relating to gender and age, but there is a significant difference where income is concerned. There is a high and strong level of correlation between the factors of service quality.
\end{abstract}

Keywords: banking, service quality, consumer, online, Internet, e-banking, India.

JEL classification: O31, O32, O33.

\section{Introduction}

The Internet banking sector has grown tremendously in many countries since the turn of the century and transformed traditional banking practices. In India, the development of Internet banking dates back to the early 1980s when the Reserve Bank of India set up two committees to accelerate the pace of operational automation in the sector (see Committee on Financial Sector Assessment, 2009).

\footnotetext{
* Department of Business Administration, Aligarh Muslim University Malappuram Centre, Kerala (email: syed.shahzeb90@gmail.com).

** Assistant professor, Department of Business Administration, Aligarh Muslim University Malappuram Centre, Kerala (email: adilcms07@gmail.com).
} 
At a basic level, Internet banking refers to the setting up of a webpage by a bank to provide information about its products and services. Sathye (1999) defines the process at a more advanced level as the "provisioning of facilities such as accessing accounts, funds transfer and buying financial products or services online." Internet banking also entails "the automated delivery of new and traditional banking products and services directly to customers through electronic and interactive communication channels" (Salehi \& Alipour, 2010).

As a medium of banking services delivery and as a strategic tool for business development, Internet banking has gained wide acceptance across the world, including in India, with more and more banks entering the fray. According to industry estimates, 7-15 percent of banks' customer base apply for Internet banking; of these registered customers, 30-40 percent use Internet banking frequently. A number of studies show that Internet banking offers opportunities in the form of smaller transaction costs, improved customer services with a unique value proposition, and larger market size (see, for example: Adil, Akhtar, \& Khan, 2013; Vinayek \& Jindal, 2011; Alagheband, 2006; Pikkarainen, Pikkarainen, Karjaluoto, \& Pahnila, 2004; Brown \& Molla, 2005; Jayawardhena \& Foley, 2000). The cost of availing Internet banking services is a fraction of the cost involved in conventional methods. Moreover, it gives rise to a "win-win" situation in which the bank's operating costs fall while its profits increase and its customers can avail banking services more conveniently.

Compared to banks abroad, however, Indian banks offering online services still have a long way to go. For online banking to reach the wider public, there need to be enough users and an adequate infrastructure in place. While various security options such as line encryption, branch connection encryption, firewalls, digital certificates, automatic signoffs, random pop-ups, and disaster recovery sites are in place or are being developed, there is as yet no certification authority offering public key infrastructure, which is necessary for online banking to become successful on a larger scale. Some of the advantages and disadvantages associated with the use of Internet banking are listed in Table 1.

The structure of this paper is as follows. Section 2 reviews the literature on the electronic service quality scale (e-S-QUAL). Section 3 presents the methodology used and Section 4 provides a data analysis and discussion. Section 5 summarizes the study's findings, recommendations, and limitations, and presents directions for future research. 
Table 1: Advantages and disadvantages of Internet banking

\begin{tabular}{ll}
\hline Advantages & \multicolumn{1}{c}{ Disadvantages } \\
\hline $\begin{array}{l}\text { Reduced cost of transactions (mailing } \\
\text { and transport to bank) }\end{array}$ & Extra cost or monthly charge/bill \\
$\begin{array}{l}\text { Availability of Internet } \\
\text { Ease of access }\end{array}$ & $\begin{array}{l}\text { Extra cost of systems and connection } \\
\text { Identity theft } \\
\text { Convenience }\end{array}$ \\
$\begin{array}{l}\text { Improved service operations } \\
\text { Profitability for the bank }\end{array}$ & \\
Customer retention & \\
\hline
\end{tabular}

Source: Adapted from Adil et al. (2013).

\section{Literature Review}

Service quality is defined as "the degree of discrepancy between customers' normative expectations for the service and their perceptions of the service performance" (Parasuraman, Zeithaml, \& Berry, 1985). Consumers tend to patronize specific shops because, apart from the level of service provided, they are "assured of certain service privileges; thus, the performance of salespeople stimulates bonding through trust between them and customers, which affects the latter's perception of the store or brand" (Lau, Cheung, Lam, \& Chu, 2013).

E-service is the electronic provision of a service to customers (Buckley, 2003) or the provision of a superior experience with respect to the interactive flow of information (Santos, 2003). Rowley (2006) emphasizes other aspects of e-service, such as effort or performance, the delivery of which is mediated by information technology (the Web, information kiosks, and mobile devices) and includes the service element of e-retailing, customer support, and service delivery. Thus, e-service delivery systems comprise three potential dimensions:

- Website design, including layout, aesthetics, and navigability.

- Information creation, selection, and quality.

- Dialogue and learning design.

Zeithaml (2002) identifies four key dimensions of qualityefficiency, reliability, fulfillment, and privacy-and defines electronic service quality (e-SQ) as the extent to which a website facilitates effective and efficient shopping, purchasing, and delivery. Customers evaluate e-SQ 
at various levels of specificity, ranging from concrete cues to perceptual attributes and from broader to higher-order dimensions as indicated in Figure 1. The four key dimensions are explained below:

1. Efficiency refers to the ability of customers to access the website, locate their desired product and the information associated with it, and check out or log off with minimal effort.

2. Fulfillment refers to the accuracy with which the promised service is delivered, i.e., the capacity for having products in stock and delivered in the time promised.

3. Reliability is associated with the technical operation of the site, particularly the extent to which it is available and functions properly.

4. Privacy includes assurances that customers' shopping behavior and information are secure.

Figure 1: Model of e-SQ

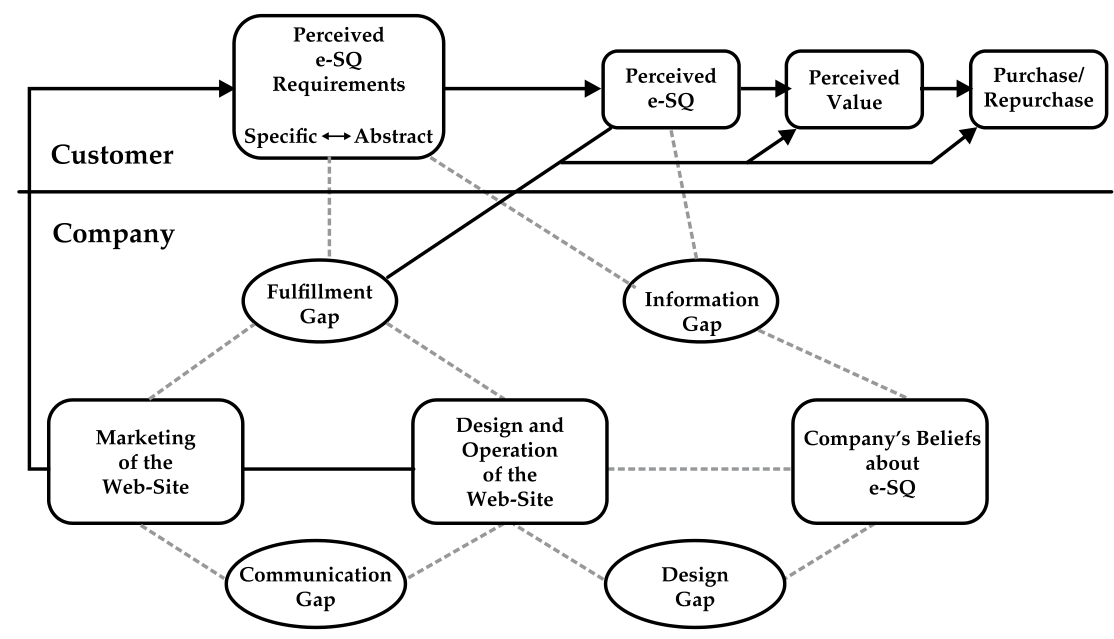

Source: Adapted from Zeithaml (2002).

Parasuraman, Zeithaml, and Malhotra (2005) have developed a multiple-item scale for assessing e-SQ, which has the following key managerial implications:

- Efficiency and fulfillment are the most critical facets of website service quality and have the strongest impact on customers' assessment of a website, overall quality perception, perceived value, and loyalty intentions. 
- Systems availability contributes significantly to customers' perception of overall quality, value, and loyalty intentions.

- Privacy emerges as the least critical of the four E-SQ dimensions.

Parasuraman et al. (2005) identify the following aspects of e-SQ: (i) access, (ii) navigability, (iii) efficiency, (iv) customization, (v) security, (vi) responsiveness, (vii) assurance, (viii) price knowledge, (ix) aesthetics, (x) reliability, (xi) flexibility, and (xii) efficiency. Each of these has a number of specific attributes. Additionally, Parasuraman (2004) has developed a conceptual gaps model for e-SQ as shown in Figure 2.

Figure 2: Gaps model of e-SQ

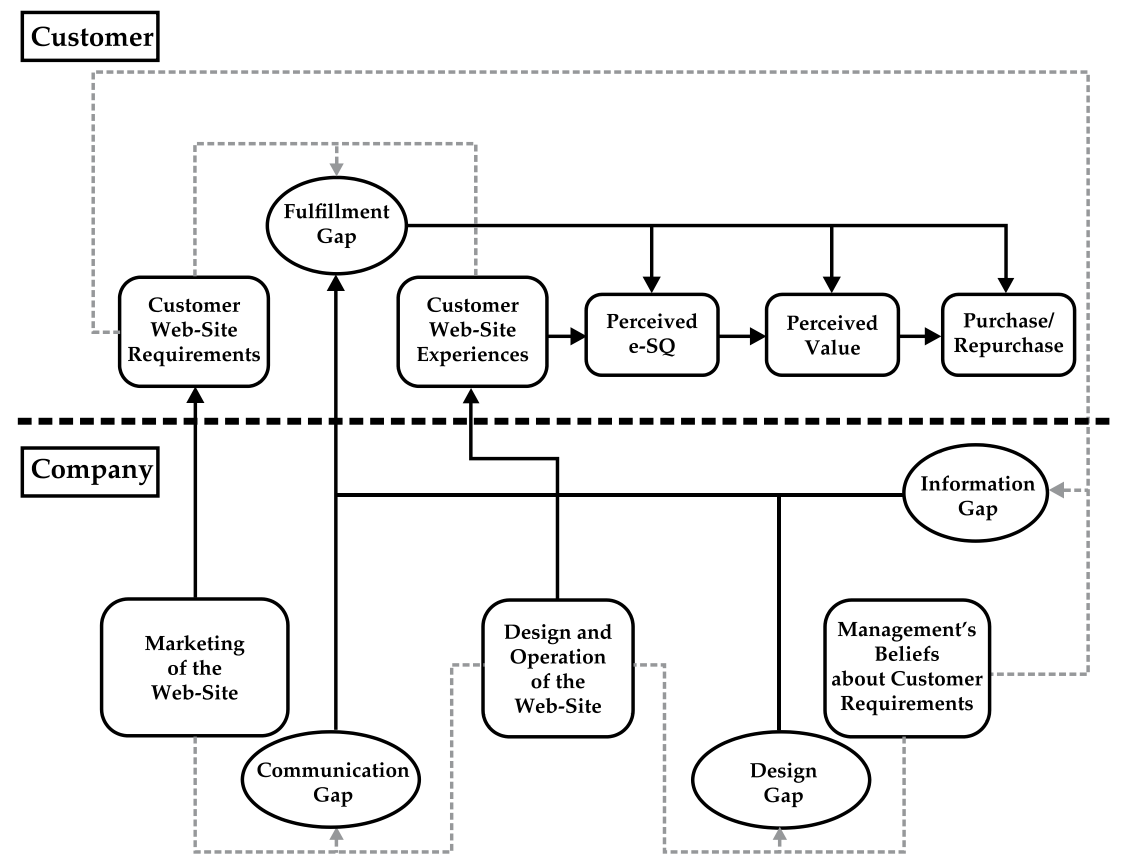

Source: Adapted from Parasuraman (2004).

\section{Research Methodology}

The study's methodology is based on descriptive research, given that its main objective is to explore customers' perception of the key service quality dimensions of Internet banking in India, i.e., (i) customer service, (ii) website design, (iii) assurance, (iv) preferential treatment, and (v) information provision. Specifically, it aims to: 
- Identify the most critical dimensions of Internet banking service quality from the perspective of bank customers.

- Determine the extent to which demographics influence the perception of Internet banking service quality factors.

- Map significant differences among customers' perceptions vis-à-vis their demographic variables across different Internet banking service quality factors.

\subsection{Hypotheses}

The study is based on the following hypotheses:

- H1: There are no significant differences between male and female respondents with respect to various dimensions of Internet banking service quality.

- H2: There are no significant differences among different age groups of respondents with respect to various dimensions of Internet banking service quality.

- H3: There are no significant differences among different income groups of respondents with respect to various dimensions of Internet banking service quality.

- H4: The five dimensions of e-SQ are highly correlated with each other.

\subsection{Survey Measures}

We have used a self-administered questionnaire to measure perceived Internet banking service quality. The questionnaire is based on the e-SQ instrument developed by Parasuraman et al. (2005) (see Table 2) and was adjusted slightly to the given context of Internet banking in India. Items 1 to 17 are measured on a five-point Likert scale where $1=$ "strongly disagree" and 5 = "strongly agree." The remaining questions relate to demographic variables such as age, gender, education, occupation, and household income. The data was collected using nominal, ordinal, and interval scales. In the final version of the questionnaire, the questions/items were scrambled to control for order bias (Malhotra, 2003).

\subsection{Sample and Data Collection}

While the geographic location of respondents was immaterial, the only criterion applied was that respondents should have personally engaged in online banking at least twice that month. We employed 
convenience-based nonprobability sampling to obtain a large number of completed questionnaires quickly and economically. Personal contacts helped initiate the administration of the instrument. A total of 340 questionnaires were administered, out of which 274 were completed, yielding a response rate of 81 percent.

\section{Table 2: E-SQ questionnaire}

\begin{tabular}{|c|c|}
\hline Factor & Item \\
\hline Customer service & $\begin{array}{l}\text { - The online process is accurate. } \\
\text { - The hyperlinks on my bank's portal site are valid. } \\
\text { - The webpage on my bank's portal site loads quickly. } \\
\text { - My bank offers the correct Internet banking services } \\
\text { the first time around. } \\
\text { - I receive prompt responses to requests sent by e-mail } \\
\text { or service line. } \\
\text { - When problems occur, my bank's Internet banking } \\
\text { system helps me resolve them. }\end{array}$ \\
\hline Web design & $\begin{array}{l}\text { - I can only complete online transactions. } \\
\text { - I can login easily to the bank's website. } \\
\text { - It is easy to understand which button to click to move } \\
\text { to the next step. } \\
\text { - My bank's Internet banking portal enables me to } \\
\text { complete transactions quickly. }\end{array}$ \\
\hline Assurance & $\begin{array}{l}\text { - Transactions carried out on my bank's portal are } \\
\text { reliable and credible. } \\
\text { - My transactions data are protected/secured by the } \\
\text { bank's website. } \\
\text { - I feel relieved at being able to transact on my bank's } \\
\text { Internet banking portal. }\end{array}$ \\
\hline $\begin{array}{l}\text { Preferential } \\
\text { treatment }\end{array}$ & $\begin{array}{l}\text { - My bank's Internet banking portal provides } \\
\text { preferential rates and charges lower fees. } \\
\text { - The transaction fee for the bank's Internet banking } \\
\text { services is reasonable. }\end{array}$ \\
\hline $\begin{array}{l}\text { Information } \\
\text { provision }\end{array}$ & $\begin{array}{l}\text { - My bank's website provides sufficient and realtime } \\
\text { financial information. } \\
\text { - The content of the bank's portal site is varied and } \\
\text { always up to date. }\end{array}$ \\
\hline
\end{tabular}

Source: Parasuraman et al. (2005). 


\section{Data Analysis and Interpretation}

This section analyzes the performance of the E-S-QUAL and discusses the results obtained.

\subsection{Reliability and Validity of the Scale}

Evaluating the scale involves assessing its reliability and validity, and the extent to which it can be generalized. Reliability refers to the extent to which the scale produces consistent results if measurements are made repeatedly; validity is the extent to which differences in observed scale scores reflect true differences among objects on the characteristic being measured rather than systematic or random error (Malhotra, 2003).

Following Cronin and Taylor (1992), Sohail and Shaikh (2008), Khan and Adil (2011), Adil (2013a, 2013b), and Adil et al. (2013), we employ Cronbach's alpha test to assess the internal consistency of items. The test is loosely equivalent to splitting the data in two in every possible way and calculating correlation coefficients for each split. The average of these values measures scale reliability. The language and layout of the questionnaire was also adjusted to improve the scale's face validity. Table 3 gives the cumulative and dimension-wise Cronbach's alpha scores for each factor. All five factors yield an alpha value higher than 0.7 , which confirms they are reliable.

Table 3: Cronbach's alpha scores

\begin{tabular}{lc}
\hline Factor & Cronbach's alpha \\
\hline Web design & 0.798 \\
Customer service & 0.793 \\
Information provision & 0.816 \\
Assurance & 0.818 \\
Preferential treatment & 0.844 \\
Overall & 0.845 \\
\hline
\end{tabular}

Source: Authors' calculations.

\subsection{T-Test Analysis}

The t-test helps judge the significance of a sample mean or the significance of difference between the means of two samples (Khan \& Adil, 2013). The results of the independent sample t-test in Table 4 show that there is no significant difference between male and female consumers' perception of the e-SQ factors. 


\subsection{ANOVA Analysis}

Analysis of variance (ANOVA) is a useful technique where more than two populations are to be compared at one time. Tables 5 and 6 give the results of a one-way ANOVA run on age and income, respectively. We find significant differences among respondents' perception of three dimensions: website design, customer service, and information provision. No significant differences are observed for the age variable.

\section{Table 4: Results of $t$-test}

\begin{tabular}{llccccc}
\hline & & \multicolumn{2}{c}{$\begin{array}{c}\text { Levene's test for } \\
\text { equality of var. }\end{array}$} & \multicolumn{2}{c}{ T-test for equality of means } \\
& \multicolumn{1}{c}{ Factor } & F & Sig. & T & df & Sig. (2-tailed) \\
\hline \multirow{2}{*}{ WD } & Equal variances assumed & 0.206 & 0.651 & -0.268 & 67.000 & 0.790 \\
& Equal variances not assumed & & & -0.261 & 19.541 & 0.797 \\
CS & Equal variances assumed & 0.400 & 0.529 & -0.513 & 67.000 & 0.609 \\
& Equal variances not assumed & & & -0.485 & 18.865 & 0.633 \\
\multirow{2}{*}{ Info } & Equal variances assumed & 0.090 & 0.765 & -0.146 & 67.000 & 0.884 \\
& Equal variances not assumed & & & -0.138 & 18.865 & 0.891 \\
\multirow{2}{*}{ ASU } & Equal variances assumed & 0.661 & 0.419 & 0.497 & 67.000 & 0.621 \\
& Equal variances not assumed & & & 0.411 & 16.638 & 0.686 \\
\multirow{2}{*}{ Pref } & Equal variances assumed & 5.016 & 0.028 & -0.101 & 67.000 & 0.920 \\
& Equal variances not assumed & & & -0.118 & 25.216 & 0.907 \\
\hline
\end{tabular}

Source: Authors' calculations.

Table 5: Results of ANOVA (income)

\begin{tabular}{llrrccc}
\hline & Factor & Sum of squares & df & Mean square & F & Sig. \\
\hline WD & Between groups & 4.828 & 3 & 1.609 & 3.219 & 0.028 \\
& Within groups & 33.494 & 270 & 0.500 & & \\
& Total & 38.322 & 273 & & & \\
& Between groups & 4.117 & 3 & 1.372 & 4.281 & 0.008 \\
& Within groups & 21.479 & 270 & 0.321 & & \\
& Total & 25.596 & 273 & & & \\
\multirow{4}{*}{ ASfo } & Between groups & 9.215 & 3 & 3.072 & 6.259 & 0.001 \\
& Within groups & 32.884 & 270 & 0.491 & & \\
& Total & 42.099 & 273 & & & \\
& Between groups & 3.108 & 3 & 1.036 & 2.111 & 0.107 \\
& Within groups & 32.883 & 270 & 0.491 & & \\
& Total & 35.991 & 273 & & & \\
& Between groups & 5.616 & 3 & 1.872 & 2.114 & 0.107 \\
& Within groups & 59.321 & 270 & 0.885 & & \\
& Total & 64.937 & 273 & & & \\
\hline
\end{tabular}

Source: Authors' calculations. 
Table 6: Results of ANOVA (age)

\begin{tabular}{|c|c|c|c|c|c|c|}
\hline & Factor & Sum of squares & df & Mean square & $\mathbf{F}$ & Sig. \\
\hline \multirow[t]{3}{*}{ WD } & Between groups & 2.298 & 3 & 0.766 & 0.899 & 0.447 \\
\hline & Within groups & 55.367 & 270 & 0.852 & & \\
\hline & Total & 57.665 & 273 & & & \\
\hline \multirow[t]{3}{*}{ CS } & Between groups & 1.375 & 3 & 0.458 & 0.668 & 0.575 \\
\hline & Within groups & 44.602 & 270 & 0.686 & & \\
\hline & Total & 45.977 & 273 & & & \\
\hline \multirow[t]{3}{*}{ Info } & Between groups & 2.241 & 3 & 0.747 & 0.926 & 0.433 \\
\hline & Within groups & 52.462 & 270 & 0.807 & & \\
\hline & Total & 54.703 & 273 & & & \\
\hline \multirow[t]{3}{*}{ ASU } & Between groups & 5.903 & 3 & 1.968 & 2.644 & 0.056 \\
\hline & Within groups & 48.367 & 270 & 0.744 & & \\
\hline & Total & 54.271 & 273 & & & \\
\hline \multirow[t]{3}{*}{ Pref } & Between groups & 0.633 & 3 & 0.211 & 0.214 & 0.887 \\
\hline & Within groups & 64.201 & 270 & 0.988 & & \\
\hline & Total & 64.833 & 273 & & & \\
\hline
\end{tabular}

Source: Authors' calculations.

\subsection{Correlation Analysis}

A high degree of correlation indicates that the scale behaves as intended (Hair et al., 2006). We find a strong, significant correlation among the five e-SQ factors, with values ranging from 0.427 to 0.717 (Figure 3).

Figure 3: Correlation analysis

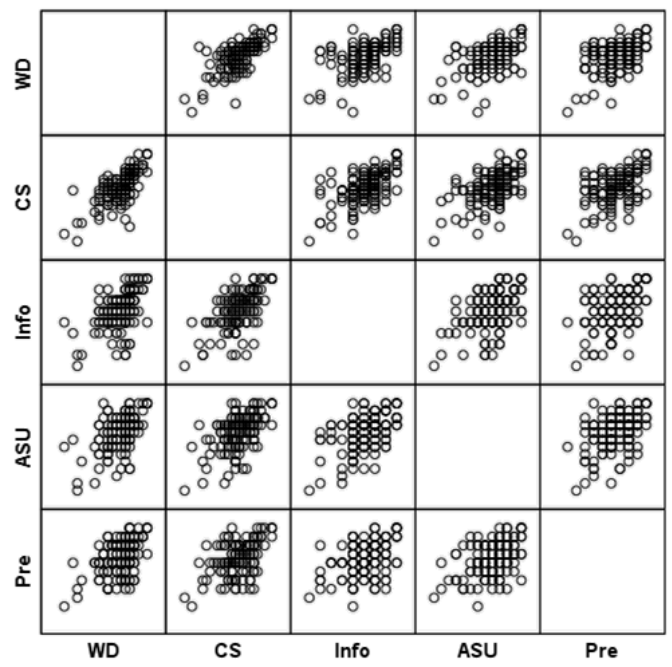

** Correlation is significant at 0.01 level (two-tailed).

* Correlation is significant at 0.05 level (two-tailed). 


\section{Findings, Recommendations, and Limitations}

The findings of the study are summarized below:

- Gender. The results of the t-test show that there is no significant difference between male and female consumers' perception of the dimensions of e-SQ.

- Age. The ANOVA results show that there are no significant differences among the e-SQ factors. Further, age does not play a major role in influencing respondents' perception of Internet banking service quality.

- Income. The ANOVA results show that there are significant differences in respondents' perception of three factors: website design, customer service, and information provision.

In general, respondents appeared to be indifferent to aspects of Internet banking service quality such as responsiveness to customer requests or complaints, the ability to resolve problems arising from Internet banking, and the accuracy of the promised services delivered online. Banks need to improve the following aspects of Internet banking services:

- Better, more closely managed service delivery systems and processes need to be put in place.

- Customer-related information stored in banks' databases should be properly managed.

- Customers should receive relevant and timely responses to their enquiries.

- Proper feedback might also include acknowledging the enquiry and committing to resolve the problem in a given time.

- Banks should be able to meet all obligations and promises made to their customers.

The study's key limitations include the following:

- Given that not all the respondents completed the survey, future research could draw on a larger sample.

- Some respondents were reluctant to provide feedback, indicating that an alternative design may have produced better results. 
- We could not properly identify the target population, making it difficult to calculate an appropriate sample size.

- The recommendations cannot be generalized if they are applicable only to selected regions of India.

- Projecting the results beyond a specific, nonprobability-based sample may not be possible. Future researchers could opt to use probabilitybased sampling techniques instead.

Given the relative novelty of online banking in India, other areas for further research could include a comparison of online banking service quality with existing traditional service quality models, for example, with respect to customer expectations and perceptions. 


\section{References}

Adil, M. (2013a). The relationship between service quality and customer satisfaction in India's rural banking sector: An item analysis and factor-specific approach. Lahore Journal of Business, 1(2), 43-63.

Adil, M. (2013b). Modeling effect of perceived service quality dimensions on customer satisfaction in Indian bank settings. International Journal of Services and Operations Management, 15(3), 358-373.

Adil, M., Akhtar, A. \& Khan, M. N. (2013). Refinement of Internet banking service quality scale: A confirmatory factor analysis approach. International Journal of Services and Operations Management, 14(3), 336-354.

Alagheband, P. (2006). Adoption of electronic banking services by Iranian customers. Unpublished Master's thesis, Luleå University of Technology, Sweden.

Alam, M. M. (2012). Customers' satisfaction measurement of Internet banking: An analytical study based on selected customers and banks in western India. Unpublished doctoral dissertation, Maharaja Sayajirao University of Baroda, Vadodara, India.

Baron, S., \& Harris, K. (2003). Services marketing: Texts and cases (2nd ed.). New York, NY: Palgrave Macmillan.

Brown, I., \& Molla, A. (2005). Determinants of Internet and cell phone banking adoption in South Africa. Journal of Internet Banking and Commerce, 20, 20-29.

Buckley, J. (2003). E-service quality and the public sector. Managing Service Quality, 13(6), 453-462.

Committee on Financial Sector Assessment. (2009). India's financial sector: An assessment. New Delhi: Reserve Bank of India.

Cronin, J. J., \& Taylor, S. A. (1992). Measuring service quality: A reexamination and extension. Journal of Marketing, 56, 55-68.

Davis, D. (2000). Business research for decision making (5 $5^{\text {th }}$ ed.). Pacific Grove, CA: Duxbury. 
Hair, Jr., J. F., Black, W. C., Babin, B. J., Anderson, R. E., \& Tatham, R. L. (2006). Multivariate data analysis (6 ${ }^{\text {th }}$ ed.). Upper Saddle River, NJ: Pearson-Prentice Hall.

Jayawardhena, C., \& Foley, P. (2000). Changes in the banking sector: The case of Internet banking in the UK. Internet Research, 10(1), 19-31.

Jun, M., \& Cai, S. (2001). The key determinants of Internet banking service quality: A content analysis. International Journal of Bank Marketing, 19(7), 276-229.

Khan, M. N., \& Adil, M. (2011). Critical factors in service delivery: A comparison of urban and rural branches of State Bank of India. International Journal of Management Development and Information Technology, 9(1), 15-23.

Khan, M. N., \& Adil, M. (2013). Data analysis techniques in service quality literature: Essentials and advances. Serbian Journal of Management, 8(1), 95-112.

Lau, M. M., Cheung, R., Lam, A. Y. C., \& Chu, Y. T. (2013). Measuring service quality in the banking industry: A Hong Kong-based study. Contemporary Management Research, 9(3), 263-282.

Malhotra, N. K. (2003). Marketing research: An applied orientation (4th ed.). New Delhi: Pearson Education.

Molapo, M. N. (2008). An assessment of Internet banking service quality. Unpublished Master's thesis, University of Johannesburg, South Africa.

Parasuraman, A. (2004). Assessing and improving service performance for maximum impact: Insights from a two-decade-long research journey. Performance Measurement and Metrics, 5(2), 45-52.

Parasuraman, A., Zeithaml, V. A., \& Berry, L. L. (1985). A conceptual model of service quality and its implications for future research. Journal of Marketing, 49, 41-50.

Parasuraman, A., Zeithaml, V. A., \& Malhotra, A. (2005). E-S-QUAL: A multiple-item scale for assessing electronic service quality. Journal of Service Research, 7(3), 213-233. 
Pikkarainen, T., Pikkarainen, K., Karjaluoto, H., \& Pahnila, S. (2004). Consumer acceptance of online banking: An extension of the technology acceptance model. Internet Research, 14(3), 224-235.

Reserve Bank of India. (2001). Report on Internet banking. Retrieved from http://www.rbi.org.in/scripts/PublicationReportDetails.aspx?Ur lPage $=\& I D=243$

Reynolds, R. A., Woods, R., \& Baker, J. D. (Eds.). (2007). Handbook of research on electronic surveys and measurements. Hershey, PA: Idea Group.

Rowley, J. (2006). An analysis of the e-service literature: Towards a research agenda. Internet Research, 16(3), 339-359.

Salehi, M., \& Alipour, M. (2010). E-banking in emerging economy: Empirical evidence of Iran. International Journal of Economics and Finance, 2(1), 201-209.

Santos, J. (2003). E-service quality: A model of virtual service quality dimensions. Managing Service Quality, 13(3), 233-246.

Sathye, M. (1999). Adoption of Internet banking by Australian consumers: An empirical investigation. International Journal of Bank Marketing, 17(7), 324-334.

Sharma, G., \& Malviya, S. (2014). Internet banking service quality and its impact on customer satisfaction in Indore district of Madhya Pradesh. International Journal of Business and Management Invention, $3(3), 1-6$.

Sohail, M. S., \& Shaikh, N. M. (2008). Internet banking and quality of service: Perspectives from a developing nation in the Middle East. Online Information Review, 32(1), 58-72.

Vinayek, R., \& Jindal, J. (2011). An empirical investigation of key antecedents of customer preference of Internet banking in Indian context. Asia Pacific Journal of Management Research and Innovation, 7(3), 63-71.

Zeithaml, V. A. (2002). Service excellence in electronic channels. Managing Service Quality, 12(3), 135-138.

Zeithaml, V. A., Bitner, M. J., \& Gremler, D. D. (2006). Services marketing: Integrating customer focus across the firm (4th ed.). New York, NY: McGraw-Hill. 